\title{
Lipoprotein glomerulopathy associated with the Osaka/Kurashiki APOE variant: two cases identified in Latin America
}

Joaquim Nelito da Silveira-Neto ${ }^{1 \dagger}$, Guilherme Jinson de Oliveira Ahn ${ }^{2 \dagger}$, Precil Diego Miranda de Menezes Neves ${ }^{3,4+}$, Vinicius Augusto Ferreira Baptista ${ }^{5}$, Stanley de Almeida Araújo ${ }^{6,7}$, David Campos Wanderley ${ }^{6,7}$, Andréia Watanabe ${ }^{3,4}$, Elieser Hitoshi Watanabe ${ }^{3,4}$, Neide Missae Murai ${ }^{1}$, Eny Maria Goloni Bertollo ${ }^{8}$, Osvaldo Merege Vieira-Neto ${ }^{2,9}$, Márcio Dantas ${ }^{2,9}$, Sergio Ricardo de Antônio ${ }^{2,9}$, Roberto Silva Costa ${ }^{10}$, Maria Alice Sperto Ferreira Baptista ${ }^{1,11}$, Miguel Moysés-Neto ${ }^{2,9}$ and Luiz Fernando Onuchic ${ }^{3,4^{*}}$

\footnotetext{
Abstract

Background: Lipoprotein glomerulopathy (LPG) is a rare autosomal dominant disease caused by mutations in APOE, the gene which encodes apolipoprotein E. LPG mainly affects Asian individuals, however occasional cases have also been described in Americans and Europeans. Herein we report two unrelated Brazilian patients with LPG in whom genetic analyses revealed the APOE-Osaka/Kurashiki variant.

Case presentation - case 1: A 29-year-old Caucasian male sought medical attention with complaints of face swelling and foamy urine for the last 3 months. He denied a family history of kidney disease, consanguinity, or Asian ancestry. His tests showed proteinuria of $12.5 \mathrm{~g} / 24 \mathrm{~h}$, hematuria, serum creatinine $0.94 \mathrm{mg} / \mathrm{dL}$, albumin $2.3 \mathrm{~g} /$ $\mathrm{dl}$, total cholesterol $284 \mathrm{mg} / \mathrm{dL}$, LDL $200 \mathrm{mg} / \mathrm{dL}$, triglycerides $175 \mathrm{mg} / \mathrm{dL}$, and negative screening for secondary causes of glomerulopathy. A kidney biopsy revealed intraluminal, laminated deposits of hyaline material in glomerular capillaries consistent with lipoprotein thrombi. These findings were confirmed by electron microscopy, establishing the diagnosis of LPG. His apolipoprotein E serum level was $72 \mathrm{mg} / \mathrm{dL}$ and genetic analysis revealed the APOE pathogenic variant c.527G > C, p.Arg176Pro in heterozygosis, known as the Osaka/Kurashiki mutation and positioned nearby the LDL receptor binding site.
}

\footnotetext{
* Correspondence: lonuchic@usp.br

${ }^{\dagger}$ Joaquim Nelito da Silveira-Neto, Guilherme Jinson de Oliveira Ahn and Precil Diego Miranda de Menezes Neves contributed equally to this work. ${ }^{3}$ Division of Nephrology, University of São Paulo School of Medicine, São Paulo, Brazil

${ }^{4}$ Division of Molecular Medicine, University of São Paulo School of Medicine, Avenida Doutor Arnaldo, 455 - Sala 4304, São Paulo, SP 01246-903, Brazil Full list of author information is available at the end of the article
}

(c) The Author(s). 2021 Open Access This article is licensed under a Creative Commons Attribution 4.0 International License, which permits use, sharing, adaptation, distribution and reproduction in any medium or format, as long as you give appropriate credit to the original author(s) and the source, provide a link to the Creative Commons licence, and indicate if changes were made. The images or other third party material in this article are included in the article's Creative Commons licence, unless indicated otherwise in a credit line to the material. If material is not included in the article's Creative Commons licence and your intended use is not permitted by statutory regulation or exceeds the permitted use, you will need to obtain permission directly from the copyright holder. To view a copy of this licence, visit http://creativecommons.org/licenses/by/4.0/. The Creative Commons Public Domain Dedication waiver (http://creativecommons.org/publicdomain/zero/1.0/) applies to the data made available in this article, unless otherwise stated in a credit line to the data. 
Case 2: A 34-year-old Caucasian man sought medical assessment for renal dysfunction and hypertension. He reported intermittent episodes of lower-limb edema for 3 years and a family history of kidney disease, but denied Asian ancestry. Laboratorial tests showed BUN $99 \mathrm{mg} / \mathrm{dL}$, creatinine $10.7 \mathrm{mg} / \mathrm{dL}$, total cholesterol $155 \mathrm{mg} / \mathrm{dL}$, LDL $79 \mathrm{mg} / \mathrm{dL}$, triglycerides $277 \mathrm{mg} / \mathrm{dL}$, albumin $3.1 \mathrm{~g} / \mathrm{dL}$, proteinuria $2.7 \mathrm{~g} / 24 \mathrm{~h}$, and negative screening for secondary causes of glomerulopathy. His kidney biopsy was consistent with advanced chronic nephropathy secondary to LPG. A genetic analysis also revealed the Osaka/Kurashiki variant. He was transplanted a year ago, displaying no signs of disease relapse.

Conclusion: We report two unrelated cases of Brazilian patients with a diagnosis of lipoprotein glomerulopathy whose genetic assessment identified the APOE-Osaka/Kurashiki pathogenic variant, previously only described in eastern Asians. While this is the second report of LPG in Latin America, the identification of two unrelated cases by our medical team raises the possibility that LPG may be less rare in this part of the world than currently thought, and should definitely be considered when nephrotic syndrome is associated with suggestive kidney biopsy findings.

Keywords: APOE gene, Apolipoprotein E, Case report, Lipoprotein, Molecular diagnosis, Kidney biopsy

\section{Background}

Lipoprotein glomerulopathy (LPG) is a rare autosomal dominant disease characterized by glomerular accumulation of lipoproteins as intracapillary thrombi [1]. It is more often reported in eastern Asian countries, however cases have also been observed in Europe and America [2-4]. LPG is caused by pathogenic variants in $A P O E$, the gene which encodes apolipoprotein $\mathrm{E}$ (ApoE). This protein is a component of lipoproteins, including highdensity lipoproteins (HDLs), very-low-density lipoproteins (VLDLs), intermediate-density lipoproteins (IDLs) and triglycerides $[1,5]$. The APOE mutations most frequently associated with LPG are the Sendai [6] and Kyoto [7] variants (p.Pro163Arg and p.Arg43Cys, respectively), but other variants have been reported (Table 1) [8-10].

This report presents two cases of unrelated Brazilian patients with nephrotic syndrome whose investigation led to a diagnosis of LPG and identified the very rare Osaka/Kurashiki $A P O E$ variant as the disease etiology.

\section{Case presentation \\ Case 1}

A 29-year-old Caucasian male sought medical attention due to face swelling and foamy urine for the past 3 months. He denied a family history of kidney disease, consanguinity, or Asian ancestry, and reported hypothyroidism with continuous use of levothyroxine $150 \mu \mathrm{g} q$ d. His physical examination revealed blood pressure within the normal range and 2+/4+ lower-limb edema.

Urinalysis showed proteinuria $(4+/ 4+)$, dysmorphic hematuria (54/high power field) and 24 -h proteinuria of $12.5 \mathrm{~g}$. Serum laboratorial tests included creatinine 0.94 $\mathrm{mg} / \mathrm{dL}$, eGFR $109 \mathrm{~mL} / \mathrm{min} / 1.73 \mathrm{~m}^{2}$ (CKD-EPI), total protein $3.6 \mathrm{~g} / \mathrm{dL}$, albumin $2.3 \mathrm{~g} / \mathrm{dL}$, cholesterol $284 \mathrm{mg} / \mathrm{dL}$, LDL $200 \mathrm{mg} / \mathrm{dL}, \mathrm{HDL} 49 \mathrm{mg} / \mathrm{dL}$, and triglycerides $175 \mathrm{mg} / \mathrm{dL}$.
Blood cell counts, serum complement and hydroelectrolytic parameters were within the normal ranges. Hepatitis B and $\mathrm{C}$ and HIV serologies were negative as well as the screening for diabetes and auto-immune diseases. Serum and urine protein electrophoresis did not detect anomalous proteins and echography revealed kidneys with normal size and features.

The patient underwent a kidney biopsy (Fig. 1) with light microscopy evincing 12 glomeruli, two of them globally sclerosed. All glomeruli with open capillary loops showed increased volume and mild expansion of mesangial matrix, with slight hypercellularity. Intraluminal deposits of hyaline material were observed in glomerular capillaries with a compact appearance, pale and laminated, leading to loop distension consistent with lipoprotein thrombi. Basement membrane thickening was detected in some capillaries, while tubular atrophy and interstitial fibrosis were present in approximately $30 \%$ of the cortical area and a mild lymphocytic infiltrate was seen in fibrotic areas. Immunofluorescence was negative for immunoglobulins and complement fractions. Electron microscopy revealed dilated glomerular capillary loops with luminal obstruction by thrombi formed by acellular and transparent material associated with vesicle formation, a pattern consistent with lipoprotein thrombi. The diagnosis of LPG was therefore established.

Serum apolipoprotein E was $7.2 \mathrm{mg} / \mathrm{dL}$ (normal range: $2.3-6.2 \mathrm{mg} / \mathrm{dL}$ ). An investigation with next-generation sequencing applied to a gene panel directed to familial hypercholesterolemia identified the pathogenic variant c.527G > C, p.Arg176Pro in APOE, called Osaka/Kurashiki [8-11], in heterozygosity (Fig. 2). This variant is not described in the gnomAD, 1000 genomes or ABRAOM databases, and the corresponding amino acid (aa) position is conserved in mammals. This variant is classified as likely pathogenic according to the American College of Medical Genetics and Genomics criteria [12], reaching 
Table 1 Description of the APOE variants associated with lipoprotein glomerulopathy, including cDNA change (nucleotide), protein change (amino acid position in pre-apoE), variant identification and amino acid position in mature apoE, and position in the protein domain structure

\begin{tabular}{|c|c|c|c|}
\hline $\begin{array}{l}\text { cDNA change } \\
\text { (nucleotide) }\end{array}$ & $\begin{array}{l}\text { Protein change (amino acid change in } \\
\text { the 317-residue pre-apoE) }\end{array}$ & $\begin{array}{l}\text { Variant identification and amino acid change in } \\
\text { the 299-residue mature apoE }\end{array}$ & Protein Domain \\
\hline c.475_483del9 & p.159_161delLRK & 141_143del (Tokyo) & $\begin{array}{l}\text { Heparan sulphate } \\
\text { proteoglycan binding site }\end{array}$ \\
\hline c.480_488del9 & p.160_162delRKL & 142_144del (Maebashi) & $\begin{array}{l}\text { Heparan sulphate } \\
\text { proteoglycan binding site }\end{array}$ \\
\hline c. $488 \mathrm{G}>\mathrm{C}$ & p.R163P & R145P (Sendai) & $\begin{array}{l}\text { Heparan sulphate } \\
\text { proteoglycan binding site }\end{array}$ \\
\hline c. $494 \mathrm{G}>\mathrm{C}$ & p.R165P & R147P (Chicago) & $\begin{array}{l}\text { Heparan sulphate } \\
\text { proteoglycan binding site }\end{array}$ \\
\hline$c .502 C>G$ & p.R168G & R150G (Okayama) & LDL receptor binding site \\
\hline c. $502 C>T$ & p.R168C & R150C (Modena) & LDL receptor binding site \\
\hline c.503G $>C$ & p.R168P & R150P (Guangzhou) & LDL receptor binding site \\
\hline c. $61 \mathrm{G}>\mathrm{T}$ & p.R43C & R25C (Kyoto) & Other sites \\
\hline c.394C>T & p.R132C & R114C (Tsukuba) & Other sites \\
\hline c. $509 \mathrm{C}>\mathrm{A}$ & p.A170D & A152D (Las Vegas) & Other sites \\
\hline $\mathrm{C} .518 \mathrm{~T}>\mathrm{C}$ & p.L173P & L155P (Chengdu) & Other sites \\
\hline c.520_573del & p.174_191del & apoE1(156-173del) & Other sites \\
\hline c.527G $>C$ & p.R176P & R158P (Osaka/Kurashiki) & Other sites \\
\hline c.644 C>G & p.S197C & S197C (Toyonaka) & Other sites \\
\hline c. $742 \mathrm{G}>\mathrm{T}$ & p.D248Y & D230Y (Hong Kong) & Other sites \\
\hline
\end{tabular}

high pathogenicity scores on SIFT (0.01) and DANN (0.996), and a moderate score on Polyphen2 (0.89). The patient remains on simvastatin $20 \mathrm{mg} \mathrm{qd}$ and ezetimib $10 \mathrm{mg}$ qd after 3 years, with serum creatinine of $2.37 \mathrm{mg} / \mathrm{dL}$ and $24-\mathrm{h}$ proteinuria of $3.7 \mathrm{~g}$.

\section{Case 2}

A 34-year-old Caucasian man came to a nephrology service for renal dysfunction and systemic hypertension. The patient reported intermittent episodes of lower-limb edema for the last 3 years. He denied Asian ancestry, but
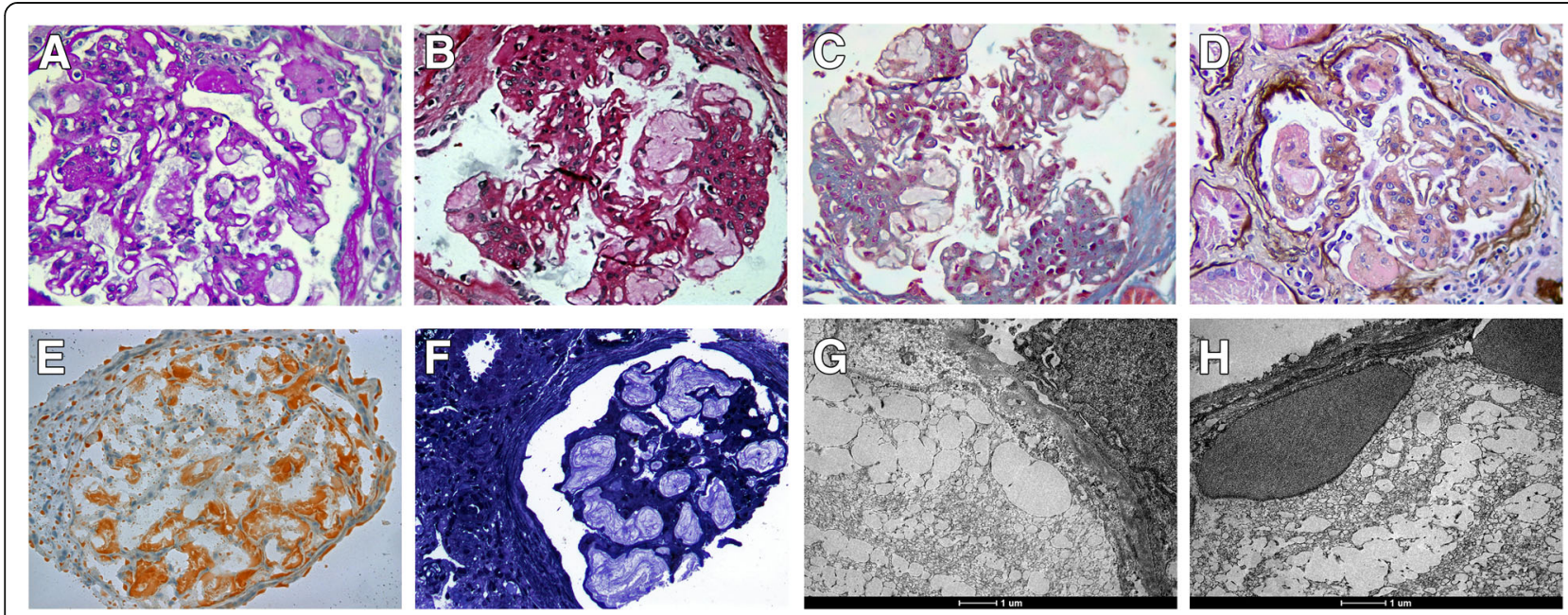

Fig. 1 Kidney biopsy. Case 2. A, B, C, D Glomerulus with increased mesangial matrix and cellularity, displaying open capillary loops filled with amorphous, acellular, lipidic and pale material observed on PAS, Picrosirius, Masson's trichrome and Jones silver methenamine staining, respectively; and E Oil Red staining showing lipidic material within the glomerular capillaries (400X). Case 1. F Toluidine blue staining revealing glomerulus with intense luminal deposition of lipidic material. Cases $2(\mathbf{G})$ and $1(\mathbf{H})$ : Transmission electron microscopy obtained after re-inclusion of paraffin-embedded material in resin, stained with osmium tetroxide and ruthenium red, showing lipoprotein pseudo-thrombi constituted of vacuolized material inside the capillary loops (16.500X magnification) 


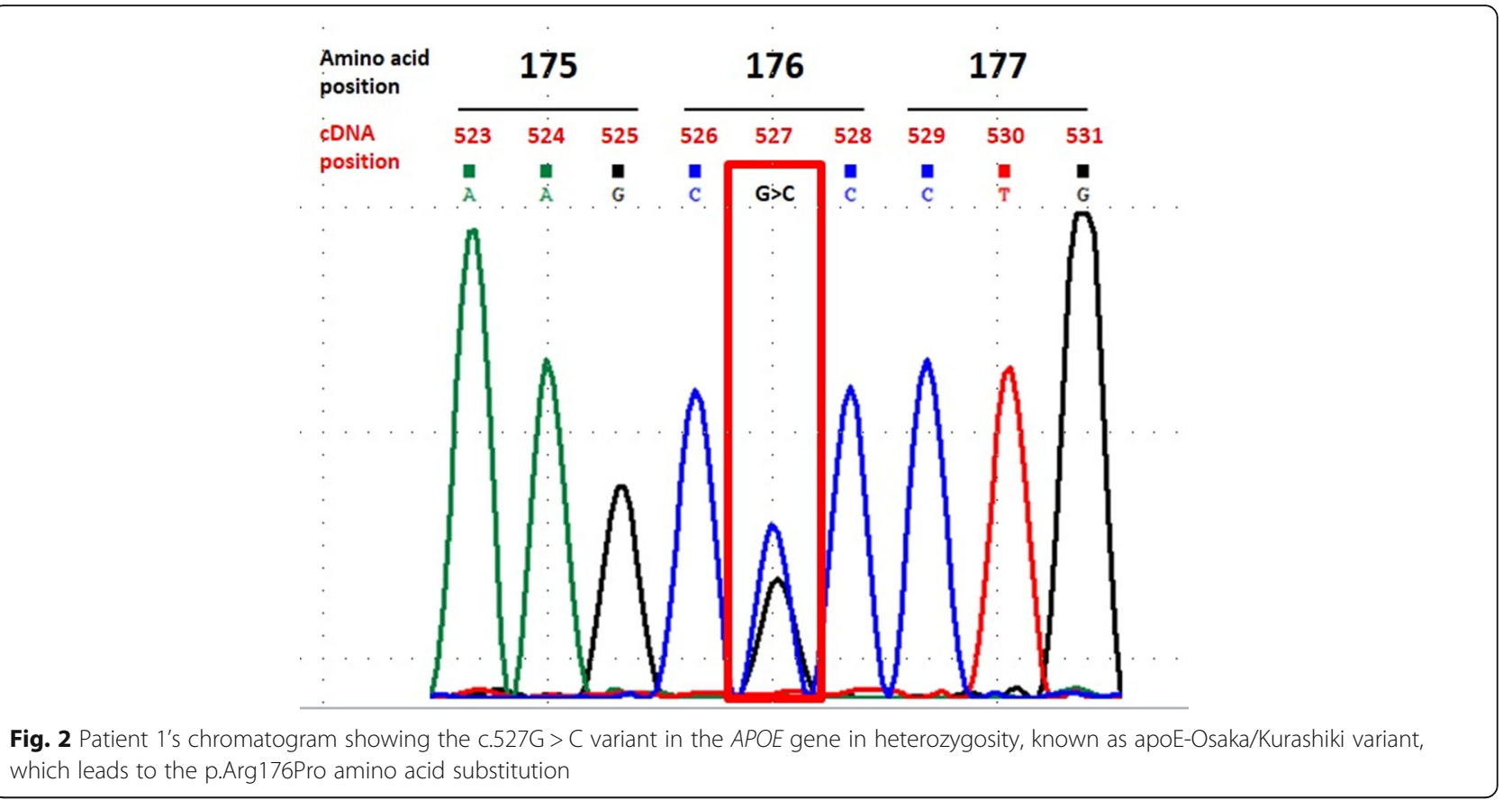

referred a family history of renal disease, affecting his sister, aunt and cousin. His physical examination revealed hypertension, but an absence of lower-limb edema.

Laboratorial tests showed BUN $99 \mathrm{mg} / \mathrm{dL}$, serum creatinine $10.7 \mathrm{mg} / \mathrm{dL}$ (CKD-EPI $5.6 \mathrm{~mL} / \mathrm{min} / 1.73 \mathrm{~m}^{2}$ ), absence of electrolytic imbalances, metabolic acidosis (venous gasometry with $\mathrm{pH} 7.25$ and bicarbonate 12 $\mathrm{mEq} / \mathrm{L}$ ), hemoglobin $6.2 \mathrm{~g} / \mathrm{dL}$, cholesterol $155 \mathrm{mg} / \mathrm{dL}$, HDL $22 \mathrm{mg} / \mathrm{dL}$, LDL $79 \mathrm{mg} / \mathrm{dL}$, triglycerides $277 \mathrm{mg} / \mathrm{dL}$, serum albumin $3.1 \mathrm{~g} / \mathrm{dL}$, and $24-\mathrm{h}$ proteinuria $2.7 \mathrm{~g}$. Serologies for hepatitis B and C and HIV and screening for auto-immune disorders and diabetes were negative. Serum and urine electrophoresis did not show abnormal protein peaks. Echographic analysis revealed a mild reduction in renal size and increased echogenicity.

A kidney biopsy showed 16 glomeruli, 14 of them globally sclerosed (Fig. 1). The two non-sclerosed glomeruli displayed endothelial cells with expanded volume obstructing the capillary lumen, cells with foamy cytoplasm, and segmental mesangial expansions. Interstitial fibrosis and tubular atrophy were diffuse and associated with hyaline arteriosclerosis. Sudan staining in a frozen specimen was positive in endothelial cells. Immunofluorescence showed $\mathrm{C} 3(+3 /+3)$ and $\operatorname{IgM}(+2 /+3)$ with segmental and global distribution following an entrapping pattern. Electron microscopy revealed dilated glomerular capillary loops with lipid droplets of variable sizes in the capillary lumen, a finding consistent with lipoprotein thrombi. These findings were consistent with advanced chronic nephropathy secondary to LPG. The patient progressed to renal replacement therapy after 2 months of conservative management. Whole exome sequencing also revealed the APOE c.527G > C, p.Arg176Pro variant in heterozygosity (Fig. 2). The patient was transplanted a year ago after 4 years on RRT.

\section{Discussion and conclusions}

Human preapoliprotein E contains 317 aa, while the cleavage of an 18-residue signal peptide gives rise to its 299-aa mature form, assembled as a homotetramer. ApoE is mainly produced in the liver and plays a significant role in lipoprotein plasma clearance. APOE encodes three apoE isoforms, apoE2, apoE3 and apoE4, with apoE3 most often being present in the general population. The p.Arg176Pro substitution hits the repeat domain 5, located near the K175 succinylation site and the LDL receptor-binding site. Eight of the 15 variants associated to LPG involve the replacement of arginine with another residue, most of them located in the LDL receptor and heparan sulphate proteoglycan binding sites or close to them. Structural abnormalities in apoE reduce its capacity to bind LDL and IDLs, impairing catabolism and their clearance, while increase its binding affinity to other molecules such as heparin. As a result, $A P O E$ mutations can lead to specific glomerular diseases, including $A P O E$ homozygote glomerulopathy, membranous nephropathy-like apoE deposition disease and lipoprotein glomerulopathy [1]. APOE mutations have been identified in most LPG cases. It must be noted that morphological findings of intraluminal pale-staining and laminated lipid or lipoprotein thrombi are strongly 
Table 2 Reported cases of Lipoprotein Glomerulopathy associated with the Osaka/Kurashiki APOE variant

\begin{tabular}{|c|c|c|c|c|c|}
\hline Number of patients & Age at diagnosis & Sex & Family history & Country & Reference \\
\hline 1 & 26 & Male & No & Japan & {$[8]$} \\
\hline 1 & 45 & Male & Not available & Japan & {$[9]$} \\
\hline 2 & $22 ; 28$ & Male; Male & Yes; No & China & [10] \\
\hline 1 & Not available & Not available & Not available & China & [11] \\
\hline 2 & $29 ; 34$ & Male; Male & No; Yes & Brazil & Our study \\
\hline
\end{tabular}

consistent with APOE glomerulopathy, even if those findings are only present in one glomerulus. Such morphological findings were in fact present in both cases, raising a high suspicion for this glomerulopathy. The only differential diagnosis is fat emboli; however, the clinical presentation is completely distinct as LPG presents itself as a proteinuric disease (most often nephrotic syndrome) and fat emboli as an acute kidney injury.

Fifteen mutations have been described up until now. While apoE-Sendai and apoE-Kyoto particularly affect Japanese and Chinese individuals, apoE-Kyoto and other $A P O E$ pathogenic variants have been found elsewhere [4]. The first Latin American case was reported in 2014 with no genetic analysis [2], whereas a previous report identified the apoE-Chicago variant in a Mexican descendant [13]. The dysfunction increases lipoprotein plasma levels and leads to forming apolipoprotein and lipoprotein glomerular deposits. Asymptomatic carriers of $A P O E$ mutations have been identified, however, and not all mice harboring the apoE-Sendai variant developed LPG, suggesting that other factors may also play a role in the disease [9].

LPG usually manifests in adulthood and predominantly affects males. Hyperlipoproteinemia type III (increased LDL and triglyceride levels), high levels of plasma apolipoproteins, proteinuria and microhematuria are common findings, and nephrotic syndrome and progressive loss of renal function are often observed. The typical LPG histology comprises glomeruli with increased size due to ectasia of capillary loops, filled with light and lamellated eosinophilic thrombi. Electron microscopy confirms small lipid vacuoles typical of lipoproteins. Specific staining for fat or apoE can be performed in frozen tissue $[1,5]$.

Only five cases harboring the Osaka/Kurashaki variant have been described so far (Table 2) [8-11]. The first patient was a 26-year-old male with no family history of consanguinity, nephropathy, or dyslipidemia [8], with mild proteinuria, no hematuria, normal renal function, hypertriglyceridemia and increased VLDL. His kidney biopsy was positive for apoE antigen in the thrombi. The patient was treated with fibrate, reaching complete remission of proteinuria in 6 months. The second patient was a 45-year-old man with proteinuria, hypertriglyceridemia, hypercholesterolemia, normal renal function, proteinuria of 1-3 g/L, mild hematuria, an increased band between LDL and VLDL, and normal apoE serum levels. Treatment with probucol normalized his serum lipid levels [9]. Two other cases have recently been described in China. These patients were 22 and 28 year-old males, one of them with a positive family history of kidney disease [10]. The last case was just reported, but we do not have access to the corresponding information [11].

By analyzing the variants R176P, R163P and R165P, Georgiadou et al. [14] suggested that the substitution of arginine to proline in those positions induces a generalized unfolding of the N-terminal domain, including mild distortion in the protein spectral structure and significant loss of the helix conformation, essential for its binding properties. They also demonstrated that these structurally defective apoE are more sensitive to digestion by proteases and more prone to thermodynamic destabilization. These findings were not restricted to proline substitutions, but also to cysteine and aspartic acid in positions 43, 132 and 170 [15].

Current treatment of LPG includes hypolipemiants, in particular fibrates. Immunoadsorption with staphylococcal protein $\mathrm{A}$ and LDL apheresis using a heparin-induced extracorporeal lipoprotein precipitation system has also yielded positive results $[1,5]$. The therapeutical roles of plasmapheresis, isolated LDL apheresis and inhibitors of Hidroxi-Methyl-Glutaril-CoA redutase are still controversial. As expected, LPG relapse in the graft has been reported in cases of kidney transplantation [16].

This is the first report of the apoE-Osaka/Kurashiki variant in non-eastern Asian patients with LPG and the third report of this disease in Latin Americans or descendants. Despite its rarity, the identification of two unrelated patients with this disease by our medical group raises the possibility that LPG may be less rare in Latin America than currently thought, and therefore should be considered in the differential diagnosis of nephrotic syndrome associated with suggestive findings in kidney biopsy.

\section{Abbreviations}

ApoE: Apolipoprotein E; HDL: High-density lipoprotein; IDL: Intermediatedensity lipoprotein; LPG: Lipoprotein glomerulopathy; VLDL: Very-low-density lipoprotein

Acknowledgements

Not applicable. 


\section{Authors' contributions}

JNSN: performed patient care and clinical follow-up; GJOA: performed patient care and clinical follow-up; PDMMN: performed and analysed genetic tests, wrote the manuscript; VAFB: performed patient care; wrote the manuscript; SAA: performed histological analysis and wrote the manuscript; DCW: performed histological analysis and wrote the manuscript; patient care; AW: performed and analysed genetic tests, wrote the manuscript; EHW: performed and analysed genetic tests, wrote the manuscript; NMM: performed patient care and clinical follow-up; EMGB: analysed genetic tests; OMVN: performed patient care and clinical follow-up; MD: performed patient care and clinical follow-up; SRA: performed patient care and clinical follow-up; RSC: performed histological analysis; MASFB: performed histological analysis and wrote the manuscript; MMN: performed patient care and clinical follow-up and wrote the manuscript; LFO: performed and analysed genetic tests, wrote the manuscript. All authors revised and approved the final version of manuscript.

\section{Funding}

Not applicable.

\section{Availability of data and materials}

All meaningful data generated or analysed in this study are included in the manuscript.

\section{Declarations}

Ethics approval and consent to participate

Not applicable.

\section{Consent for publication}

Written informed consent for publication was obtained from both patients.

\section{Competing interests}

The authors declare that they have no competing interests.

\section{Author details}

'Division of Nephrology, Hospital de Base, FAMERP/FUNFARME, São Jose do Rio Preto, Brazil. ${ }^{2}$ Nephrology Service of Ribeirão Preto, Ribeirão Preto, Brazil. ${ }^{3}$ Division of Nephrology, University of São Paulo School of Medicine, São Paulo, Brazil. ${ }^{4}$ Division of Molecular Medicine, University of São Paulo School of Medicine, Avenida Doutor Arnaldo, 455 - Sala 4304, São Paulo, SP 01246-903, Brazil. ${ }^{5}$ Catanduva Medical School, Catanduva, Brazil. ${ }^{6}$ Division of Pathology, Federal University of Minas Gerais, Belo Horizonte, Brazil. ${ }^{7}$ Nephropathology Institute, Belo Horizonte, Brazil. ${ }^{8}$ Genetic Service, Hospital de Base, FAMERP/FUNFARME, São Jose do Rio Preto, Brazil. ${ }^{9}$ Division of Nephrology, Ribeirão Preto School of Medicine - University of São Paulo, Ribeirão Preto, Brazil. ${ }^{10}$ Division of Pathology, Ribeirão Preto School of Medicine - University of São Paulo, Ribeirão Preto, Brazil. "'Division of Renal Pathology, Hospital de Base, FAMERP/FUNFARME, São Jose do Rio Preto, Brazil.

Received: 29 March 2021 Accepted: 8 June 2021

Published online: 26 July 2021

\section{References}

1. Saito T, Matsunaga A, Fukunaga M, Nagahama K, Hara S, Muso E. Apolipoprotein E-related glomerular disorders. Kidney Int. 2020;97(2):279-88. https://doi.org/10.1016/j.kint.2019.10.031.

2. Pegas KL, Rohde R, Garcia CD, Bittencourt Vde B, Keitel E, Poloni JA, et al. Lipoprotein glomerulopathy: a case report of a rare disease in a Brazilian child. J Bras Nefrol. 2014;36(1):93-5. https://doi.org/10.5935/01 01-2800.20140015

3. Rovin BH, Roncone D, McKinley A, Nadasdy T, Korbet SM, Schwartz MM. APOE Kyoto mutation in European Americans with lipoprotein glomerulopathy. N Engl J Med. 2007;357(24):2522-4. https://doi.org/10.1056/ NEJMC072088

4. Bomback AS, Song H, D'Agati VD, Cohen SD, Neal A, Appel GB, et al. A new apolipoprotein E mutation, apoE Las Vegas, in a European-American with lipoprotein glomerulopathy. Nephrol Dial Transplant. 2010;25(10):3442-6. https://doi.org/10.1093/ndt/gfq389.
5. Cambruzzi E, Pegas KL. Pathogenesis, histopathologic findings and treatment modalities of lipoprotein glomerulopathy: a review. J Bras Nefrol. 2019;41(3):393-9. https://doi.org/10.1590/2175-8239-jbn-2018-0148.

6. Oikawa S, Matsunaga A, Saito T, Sato H, Seki T, Hoshi K, et al. Apolipoprotein E Sendai (arginine 145-->proline): a new variant associated with lipoprotein glomerulopathy. J Am Soc Nephrol. 1997;8(5):820-3. https://doi.org/10.1 681/ASN.V85820.

7. Matsunaga A, Sasaki J, Komatsu T, Kanatsu K, Tsuji E, Moriyama K, et al. A novel apolipoprotein E mutation, E2 (Arg25Cys), in lipoprotein glomerulopathy. Kidney Int. 1999;56(2):421-7. https://doi.org/10.1046/j.1 523-1755.1999.00572.x

8. Mitani A, Ishigami M, Watase K, Minakata T, Yamamura T. A novel apolipoprotein E mutation, ApoE Osaka (Arg158 pro), in a dyslipidemic patient with lipoprotein glomerulopathy. J Atheroscler Thromb. 2011;18(6): 531-5. https://doi.org/10.5551/jat.7377.

9. Tokura T, Itano S, Kobayashi S, Kuwabara A, Fujimoto S, Horike H, et al. A novel mutation ApoE2 Kurashiki (R158P) in a patient with lipoprotein glomerulopathy. J Atheroscler Thromb. 2011;18(6):536-41. https://doi.org/10. 5551/jat.8102.

10. Yang M, Weng Q, Pan X, Hussain HMJ, Yu S, Xu J, et al. Clinical and genetic analysis of lipoprotein glomerulopathy patients caused by APOE mutations. Mol Genet Genomic Med. 2020 Aug;8(8):e1281. https://doi.org/10.1002/ mgg3.1281.

11. Yang Z, Wu H, Hu Z. Discovery of a Chinese Tibetan patient with lipoprotein glomerulopathy due to APOE Osaka/Kurashiki variant. Zhonghua Yi Xue Yi Chuan Xue Za Zhi. 2020;37(2):166-9. https://doi.org/10.3760/cma.j. issn.1003-9406.2020.02.017.

12. Richards S, Aziz N, Bale S, Bick D, Das S, Gastier-Foster J, et al. Standards and guidelines for the interpretation of sequence variants: a joint consensus recommendation of the American College of Medical Genetics and Genomics and the Association for Molecular Pathology. Genet Med. 2015; 17(5):405-24. https://doi.org/10.1038/gim.2015.30.

13. Sam R, Wu H, Yue L, Mazzone T, Schwartz MM, Arruda JAL, et al. Lipoprotein glomerulopathy: a new apolipoprotein $\mathrm{E}$ mutation with enhanced glomerular binding. Am J Kidney Dis. 2006:47(3):530-48.

14. Georgiadou D, Stamatakis K, Efthimiadou EK, Kordas G, Gantz D. Thermodynamic and structural destabilization of apoE3 by hereditary mutations associated with the development of lipoprotein glomerulopathy. Jipid Res. 2013;54(1):164-76. https://doi.org/10.1194/jlr.M030965.

15. Katsarou M, Stratikos E, Chroni A. Thermodynamic destabilization and aggregation propensity as the mechanism behind the association of apoE3 mutants and lipoprotein glomerulopathy. J Lipid Res. 2018;59(12):2339-48. https://doi.org/10.1194/jlr.M088732.

16. Foster K, Matsunaga A, Matalon R, Saito T, Gallo G, D'Agati V, et al. A rare cause of posttransplantation nephrotic syndrome. Am J Kidney Dis. 2005; 45(6):1132-8. https://doi.org/10.1053/j.ajkd.2004.08.048.

\section{Publisher's Note}

Springer Nature remains neutral with regard to jurisdictional claims in published maps and institutional affiliations.
Ready to submit your research? Choose BMC and benefit from:

- fast, convenient online submission

- thorough peer review by experienced researchers in your field

- rapid publication on acceptance

- support for research data, including large and complex data types

- gold Open Access which fosters wider collaboration and increased citations

- maximum visibility for your research: over $100 \mathrm{M}$ website views per year

At BMC, research is always in progress.

Learn more biomedcentral.com/submissions 